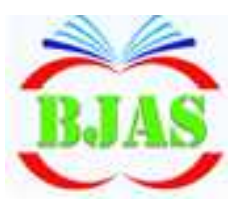

ISSN $1814-5868$
Available online at http://journal.bajas.edu.iq

College of Agriculture, University of Basrah

DOi:10.21276/basjas
Basrah Journal

of Agricultural

Sciences

E-ISSN: 2520-0860

\title{
Agroecosystem Management Practices on some Cucumber Plant Parameters using Integrated Fertilization under Green House
}

\author{
Akram M. Abdul Rahman ${ }^{1 *}$ \& Allaaddin Yüksel ${ }^{2}$ \\ ${ }^{1}$ Sulaimaniyah Agricultural Research Center, Bekrajo, Sulaimaniyah, Iraq \\ ${ }^{2}$ Departments of Soil Science \& Plant Nutrition, Faculty of Agricultural, University of \\ Bingöl, Turkey
}

*Corresponding author e-mail: absrh2010@gmail.com

Received 26 July 2018; Accepted 28 January 2019; Available online 12 February 2019

\begin{abstract}
This study was conducted in Tainal watershed, Bazian City, west of Sulaimaniyah, north of Iraq (35'57'31' $\mathrm{N}, 45^{\circ} 17^{\prime} 98^{\prime}$ ' $\left.\mathrm{E}\right)$, the soil fertility was analyzed before the application of kinds of soil biofertilizer like dry yeast Saccharomyces cerevisiae with two concentrations $\left(5 \mathrm{~g}^{-\mathrm{L}}, 10 \mathrm{~g}^{-\mathrm{L}}\right)$ of dry yeast. Biofertilizers, organic matter like humic acid and chemical fertilizer for more comparison and water as a control. Results using dry yeast $\left(10 \mathrm{~g}^{-\mathrm{L}}\right)$ have significant differences in $(\mathrm{P} \leq 0.05)$ on the vegetable parameters, plant height, leaf area, yield, the number of harvest day and the weight of root system. Also the humic acid and biofertilizers have a significant effect $(\mathrm{P} \leq 0.05)$. The yeast $(10 \mathrm{~g} / \mathrm{L})$ have significant differences on $(\mathrm{P} \leq 0.05)$ on yield $(1.3$ ton/ha) comparing with control of $48.73 \mathrm{~kg} / 5 \mathrm{~m}^{2}$, and the total leaf area of $1.5 \mathrm{~m}^{2}$ comparing with the control $1.16 \mathrm{~m}^{2}$. The experiment was performed as factorial with randomized completely block design (R.C.B.D) on Cucumber plant type of (SAIF F1) with three replicates; each unit from the 18 unite (plot) contained 18 cucumber plant. The data were analyzed by using XLSTAT program statistically analyst.
\end{abstract}

Keywords: Agroecosystem Management, Cucumber, Non-Chemical Fertilizer, Soil fertility.

\section{Introduction}

During the last century, people who live on watersheds in any ecosystem faced many challenges which mitigating the effects of all of the changes that adversely affect human welfare and the functioning of natural ecosystems; the use of modern agricultural technologies raising yield has become an effective substitute for land expansion (Wilde, 2013). These issues have increased public awareness of soil Ecology and the significance of maintaining soil health in the agroecosystem (Wang \& McSorley 2005).

Being intensively cultivated with high yielding crops needs to be carried executed (Vollrath, 2011). Soil testing is usually followed by collecting composite soil samples in the fields without geographic reference. The results of such soil testing are not useful 
for site-specific recommendations and subsequent monitoring soil obtainable nutrients status of using GPS will help in formulating site-specific balanced fertilizer recommendation and to understand the status of soil fertility spatially and temporally (Patil et al., 2012). The beneficial effects of using natural improve on soil fertility have been repeatedly shown yet; there are no procedures for their management (Bauer \& Black, 1994). Many of organic materials functions with respect to soil fertility are known. Organic or biological compounds influence nutrient availability (i) by nutrients added, (ii) through mineralization-immobilization patterns, (iii) as an energy source for microbial activities, (iv) as precursors to soil organic matter (SOM), and (v) by reducing P sorption of the soil. The challenge is to merge organics of differing quality with inorganic fertilizers to optimize nutrient availability to plants (Palm et al., 1997). Results of research made on organic and synthetic fertility amendments influence soil microbial, physical and chemical properties of the yields were higher on farms with sort of organic production regardless of soil amendment type (Bonanomi et al., 2014). Alternative fertility amendments enhanced beneficial soil microorganisms decreased pathogen populations, increased soil organic matter, total carbon, and cation exchange capacity (CEC), and lowered bulk density thus improving soil quality (Bulluck et al., 2002). Cucumber is a popular cultivated plant in the gourd family Cucurbitaceae. Over 4000 years ago, the cucumber was spread beyond Indian borders, moved through Ancient Greece, Rome, Europe, New World, China, and eventually becoming fourth most widely cultivated vegetable in the globe (Siful, 2008). This journey was filled with golden periods when they were viewed as integral parts of many culture's cuisines, and sometimes they were dealt with as bringers of disease. In 2010, worldwide cucumber production was 57.5 million tons; the majority of the world's production and export being located in China (40.7 million tons). Cucumber (Cucumis sativus L.) is an important vegetable crop in our region especially in Sulaimaniyah province which has almost 3000 greenhouses; and $\% 50$ of them are cultivating with cucumber. Bacterial fertilizers of the preparation of living bacteria are applied to improve soil and increase the yield, the culture of nodule bacteria (Rhizobium spp.) have long been used extensively for this purpose and no controversy exists over their usefulness (Maurya et al., 2015).

\section{Material and Methods}

\section{Site of Experiment}

A-Bazian located in Kurdistan region Northeast of Iraq, $20 \mathrm{~km}$. southwest of Sulaimaniyah province, $35 \mathrm{~N}$ latitude, and 45 E longitude, big and important agricultural city that contain at least 4000 greenhouses, sea surface level reach it $(837 \mathrm{~m}-847 \mathrm{~m})$ also located in Basarah Basin (Fig. 1) that located in high folded zone, it has a wide plain with slightly slope topography called Bazian Plain. It contains six Watersheds and 14 Microcatchments (Barzinji, 2013).

B-Stream flow: Basrah Basin has many springs, kameezes. Basrah Basin has a perennial mainstream, which consists of the combination of two great streams which are Tilie stream and Chami Tainal stream (Barzinji, 2013).

\section{Climate}

In winter, Bazian climate is cold and rainfall getting to the freezing point at the end of January and February, in middle and end of December snowfall be the higher and rainfall quantities reach it $800 \mathrm{~mm}-1000 \mathrm{~mm} /$ year. In summer climate is hot and dry getting to $45^{\circ} \mathrm{c}$, in September wind is faster compared to other months also in June wind is faster but not like in September as shown in Table (1).

\section{Soil}

The experiment was carried out in normal greenhouses in Bazian city which located in $35^{\circ} 57^{\prime} 31^{\prime}$ 'N , 45 $17^{\circ} 98^{\prime \prime} \mathrm{E}$, and all agricultural practices were done in an organic way without using any chemical or pollute sources starting from plowing; the plow and all materials were sterilized by absolute ethanol $\left(\mathrm{C}_{2} \mathrm{H}_{5} \mathrm{OH}, 35 \%\right)$ as observed in (Table 2). 


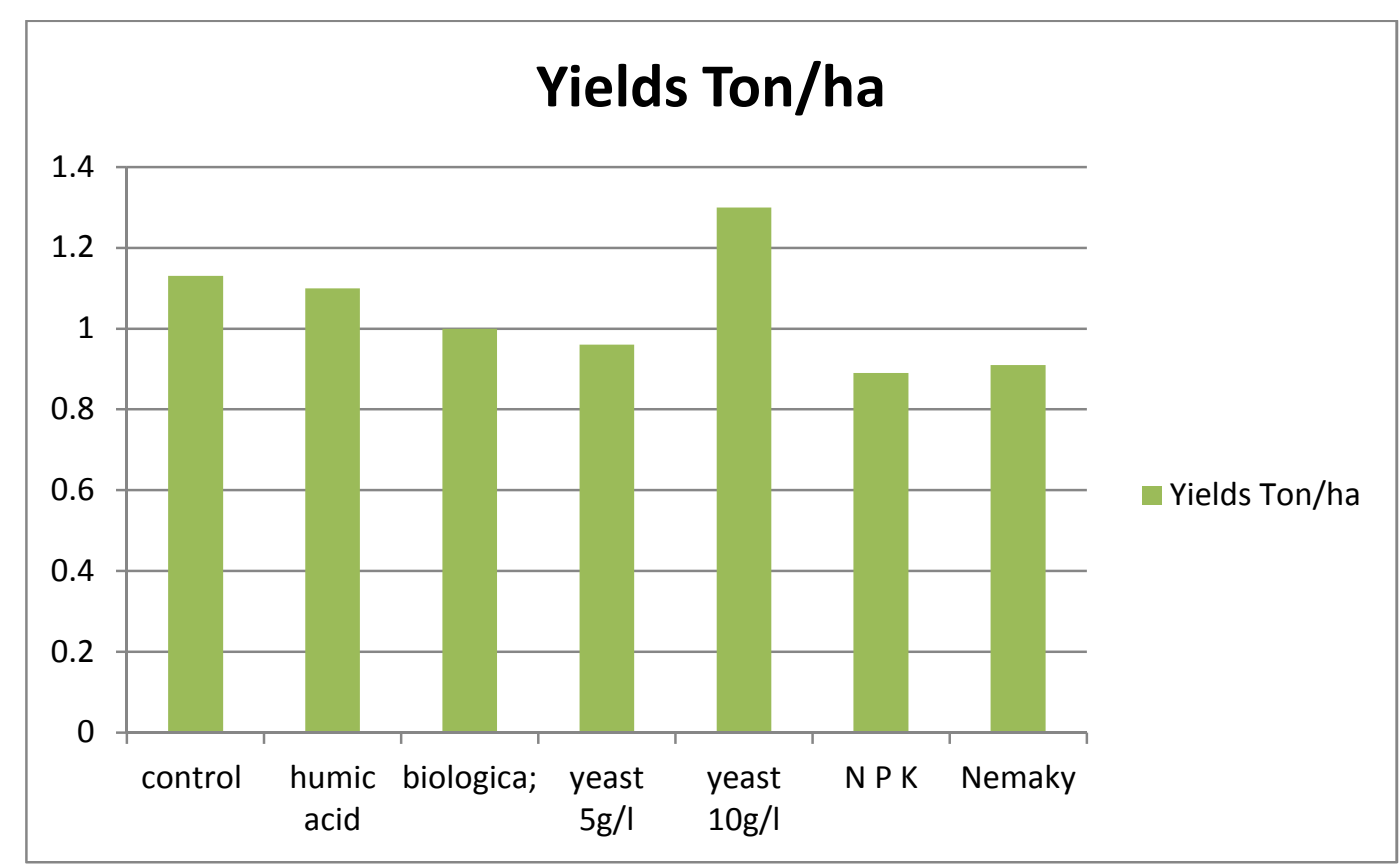

Fig. (1): Effect of treatments on cucumber yield $\left(\mathrm{kg} / \mathrm{m}^{2}\right)$ between April-August 2016.

Table (1): Average of climate data for Bazian city, 2016.

\begin{tabular}{|c|c|c|c|c|c|c|c|c|}
\hline \multirow[t]{2}{*}{ Months } & \multicolumn{3}{|c|}{ Temperature $\left({ }^{\circ} \mathrm{C}\right)$} & \multirow{2}{*}{$\begin{array}{c}\text { Precipitati } \\
\text { on (rain) } \\
\text { mm. }\end{array}$} & \multirow{2}{*}{$\begin{array}{c}\text { Humidity } \\
\text { (\%) }\end{array}$} & \multirow{2}{*}{$\begin{array}{c}\text { Sun } \\
\text { (hours) }\end{array}$} & \multirow{2}{*}{$\begin{array}{c}\text { Pressure } \\
\text { (Mb) }\end{array}$} & \multirow{2}{*}{$\begin{array}{c}\text { Wind } \\
\text { speed } \\
(\mathbf{M} / \mathrm{hr} .)\end{array}$} \\
\hline & Max. & Min. & Mean & & & & & \\
\hline Feb 2016 & 15 & 4 & 11 & 69.5 & 59 & 73 & 1021.1 & 6.5 \\
\hline Mar 2016 & 17 & 6 & 15 & 175.4 & 147 & 106.3 & 1015.1 & 10.5 \\
\hline Apr 2016 & 24 & 10 & 20 & 73.9 & 38 & 136 & 1013.1 & 9.4 \\
\hline May 2016 & 30 & 17 & 25 & 19.9 & 23 & 146 & 1010.5 & 11.4 \\
\hline Jun 2016 & 37 & 21 & 31 & 3.8 & 16 & 149.8 & 1007.4 & 12.3 \\
\hline Jul 2016 & 42.1 & 25 & 34.5 & 0 & 13 & 155 & 1002.8 & 11.6 \\
\hline Aug 2016 & 42 & 24 & 36 & 0 & 22 & 154.8 & 1006 & 10.1 \\
\hline
\end{tabular}

\section{Treatments and experimental design.}

X.L.STAT program used for statistical analysis. Type of research design was R.C.B.D.. Numbers of treatments $=7$, Numbers of replications $=3$, Distance of treatments (sow line) $=5 \mathrm{~m}$, Width of terraces or plot (unite experiments) $=1 \mathrm{~m}$, High of the terraces $30 \mathrm{~cm}$., Area of plot $=5 \mathrm{~m}^{2}$, Distance between each plots $=$ in the same line
$=1 \mathrm{~m}$, Numbers of sow lines in each treatments 2 line zigzag way. Distance between each two plant $=40 \mathrm{~cm}$. Numbers of guard line $=2$. Numbers of plant in each plot $=18$ cucumbers plant. Numbers of plants selected for parameters and data's $=10$. Distance between each feed line $40 \mathrm{~cm}$. Table (3) explains the procedure used for soil analyses. 
Table (2): Soil analysis for soil samples before the research.

\begin{tabular}{|c|c|}
\hline Analysis element & Before \\
\hline Soil texture & Clay loam \\
\hline E.C./ ds. m. & 0.28 \\
\hline $\mathrm{pH}$ & 7.76 \\
\hline $\mathrm{N} \%$ & 0.14 \\
\hline Available $\mathrm{P}(\mathrm{ppm})$ & 15.18 \\
\hline Soluoble $\mathrm{K}+(\mathrm{mg} / \mathrm{l})$ & 0.1 \\
\hline Soluble $\mathrm{Na}+(\mathrm{mg} / \mathrm{l})$ & 0.17 \\
\hline Soluble $\mathrm{Ca}+(\mathrm{mg} / \mathrm{l})$ & 1.9 \\
\hline Soluble $\mathrm{Mg}+(\mathrm{mg} / \mathrm{l})$ & 3.6 \\
\hline $\mathrm{Cl}{ }^{-} \mathrm{mg} / \mathrm{l}$ & 0.4 \\
\hline $\mathrm{O}_{\mathrm{M} .} \%$ & 2.06 \\
\hline $\mathrm{CaCo}_{3} \%$ & 27 \\
\hline $\mathrm{HCO}_{3} \mathrm{mg} / \mathrm{l}$ & 1.7 \\
\hline $\mathrm{CO}^{-3} \mathrm{mg} / \mathrm{l}$ & 0.3 \\
\hline
\end{tabular}

* O.M.: Organic matter.

\section{Methods: Distribution of treatment.}

1- Control (T1).

2- Humic acid (T2).

Adding $1 \mathrm{~mm} /$ plant to the soil before planting (7-10 days).

Adding $1 \mathrm{~mm} /$ plant to the soil after planting (15 days).

Adding $1 \mathrm{~mm} /$ plant to the soil during flowering.

Adding $1 \mathrm{~mm} /$ plant to the soil before planting (7-10 days).

Adding $1 \mathrm{~mm} /$ plant to the soil at first fruiting.

Adding $1 \mathrm{~mm} /$ plant to the soil after one, two and three months.

3-Infoxgen a Biological fertilizer Austrian origin (T3): According to the recommendation on the box.

With planting when watering concentration (25 $\mathrm{g} \backslash 1$ of water).

After the planting (20 days) in the same concentration.

After the First harvest directly concentration (30 $\mathrm{g} \backslash 1$ of water).
Table (3): Procedures for soil analysis.

\begin{tabular}{|c|c|}
\hline Analysis type & Procedure \\
\hline Soil Texture & Bouyoucos (1936) \\
\hline E.C. & Richards (1954) \\
\hline $\mathrm{pH}$ & McLean (1982) \\
\hline $\mathrm{N} \%$ & Kjeldahl \\
\hline $\mathrm{Available} \mathrm{P}$ & Olsen et al. (1954) \\
\hline $\mathrm{K}, \mathrm{Na}, \mathrm{Ca}, \mathrm{Mg}, \mathrm{Cl}$ & Richards (1954) \\
\hline $\mathrm{O} . \mathrm{M} . \% *$ & Walkley \& Black (1934) \\
\hline $\mathrm{CaCo} \%$ & FAO (1976) \\
\hline $\mathrm{HCO}_{3} \mathrm{CO}_{3}$ & Richards (1954) \\
\hline
\end{tabular}

* O.M.: Organic matter.

A month after the first harvest concentration (30 $\mathrm{g} \backslash 1$ of water).

Two months after first harvest concentration (30 $\mathrm{g} \backslash 1$ of water).

4-Fungus (Saccharomyces cerevisiae) of bread yeast (Commercial dry yeast) added to the soil with two concentrations:

$5 \mathrm{~g} \backslash 1$ of water (T4).

$10 \mathrm{~g} \backslash 1$ of water (T5).

5- Chemical fertilizer (NPK) 20:20:20 (T6).

Adding $1.5 \mathrm{gm} /$ plant to the soil before planting by (10) days, and in the middle of the season and before the seasons end in one month.

6-Vegetable extracts (Nemakey) (T7) add $\left(1 \mathrm{~mm} \backslash \mathrm{m}^{2}\right)$ to the soil before planting, with first fruiting and after one month.

\section{Results and Discussion}

The results of table (4) and Fig. (2) indicated that the highest significant was in cucumber yield (1.3 ton/ha) when using of $10 \mathrm{~g} / \mathrm{plant}$ yeast; the reason of the increasing of yield because of yeast which contains a growth regulator like oxiness, gabbiness, carbohydrate and other important elements for growing (Joshi, et al., 2009). Using humic acid gave a significant effect on yield (1.1 ton/ha), because of humic ability to soil 
solution and increase the plant's uptake for elements.

Day to harvesting made significant difference on the treatments of yeast (10g/plant yeast); Albrecht et al. (1997) reported that might be due to induces nutrient minerals absorption through improvement of soil pH. Bown \& Rovira (1991) and Sarhan (2008) indicated the yeast ability to increase the production of stimulants for plant growth, especially Gibberellins, Auxins and
Cytokinins which act to improve the plant cell division and its growth results showed when they increase of yeast extract up to $\left(10 \mathrm{~g}^{-\mathrm{L}}\right)$ improved the vegetative growth characters as expressed as plant length, stems and leaves number/plant, leaf area/plant, fresh and dry weights of the whole plant. Biofertilizer treatment affected significantly by decreasing the number of days needed to harvest (Larkin, 2008).

Table (4): Effect of fertilizers on some parameters.

\begin{tabular}{|c|c|c|c|c|c|c|}
\hline Treat. & $\begin{array}{c}\text { Yields } \\
\text { Ton/ha }\end{array}$ & $\begin{array}{c}\text { Day to } \\
\text { Harvesting }\end{array}$ & $\begin{array}{c}\text { Leaf area } \\
\mathbf{C m}^{2}\end{array}$ & $\begin{array}{c}\text { The weight of } \\
\text { the shoot } \\
\text { system } \mathbf{k g}\end{array}$ & $\begin{array}{c}\text { The weight of the } \\
\text { root system, } \mathbf{k g}\end{array}$ & TSS \\
\hline Treat.1 & $1.13 \mathrm{c}$ & $62 \mathrm{~b}$ & $1.16 \mathrm{c}$ & $3.45 \mathrm{~b}$ & $1.35 \mathrm{~b}$ & $3 \mathrm{~b}$ \\
\hline Treat.2 & $1.10 \mathrm{~b}$ & $56 \mathrm{a}$ & $1.46 \mathrm{~b}$ & $4.55 \mathrm{a}$ & $2 \mathrm{ab}$ & $7 \mathrm{~b}$ \\
\hline Treat.3 & $1 \mathrm{~b}$ & $59 \mathrm{~b}$ & $1.4 \mathrm{~b}$ & $3.88 \mathrm{a}$ & $1.82 \mathrm{ab}$ & $6 \mathrm{~b}$ \\
\hline Treat.4 & $0.96 \mathrm{c}$ & $61.3 \mathrm{~b}$ & $1.21 \mathrm{c}$ & $3.75 \mathrm{a}$ & $1.74 \mathrm{ab}$ & $7 \mathrm{~b}$ \\
\hline Treat.5 & $1.30 \mathrm{a}$ & $50 \mathrm{a}$ & $1.5 \mathrm{a}$ & $4.6 \mathrm{a}$ & $2.39 \mathrm{a}$ & $8.3 \mathrm{a}$ \\
\hline Treat.6 & $0.89 \mathrm{c}$ & $61 \mathrm{~b}$ & $1.1 \mathrm{c}$ & $3.35 \mathrm{~b}$ & $1.5 \mathrm{~b}$ & $6 \mathrm{~b}$ \\
\hline Treat. 7 & $0.91 \mathrm{c}$ & $62 \mathrm{~b}$ & $1.2 \mathrm{c}$ & $3.4 \mathrm{~b}$ & $1.55 \mathrm{~b}$ & $6 \mathrm{~b}$ \\
\hline
\end{tabular}

Means with different letters are significantly different according to Duncan's multiple ranges test at $P \leq 0.0$.

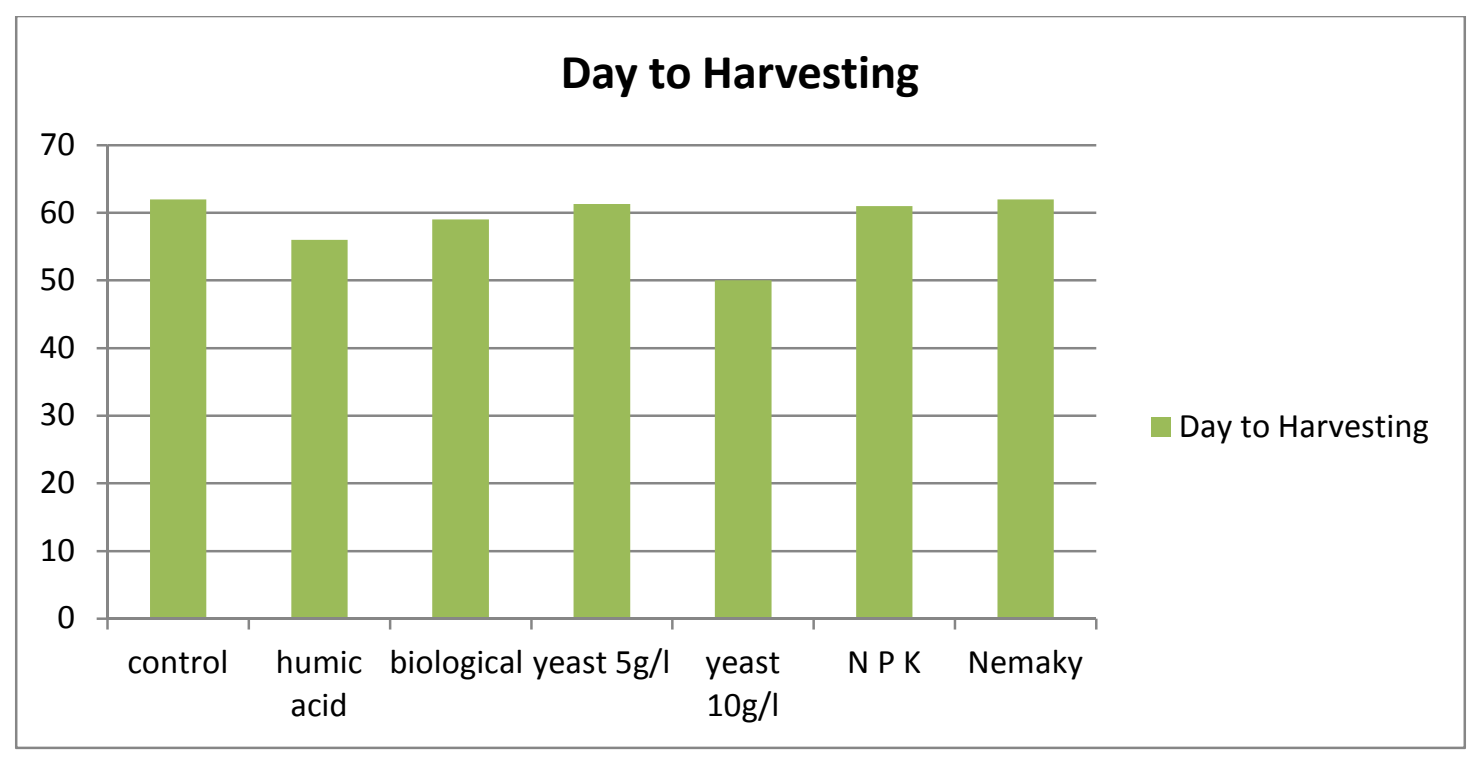

Fig. (2): Effect of treatments on cucumber yield $\left(\mathrm{kg} / \mathrm{m}^{2}\right)$ between April-August 2016. 


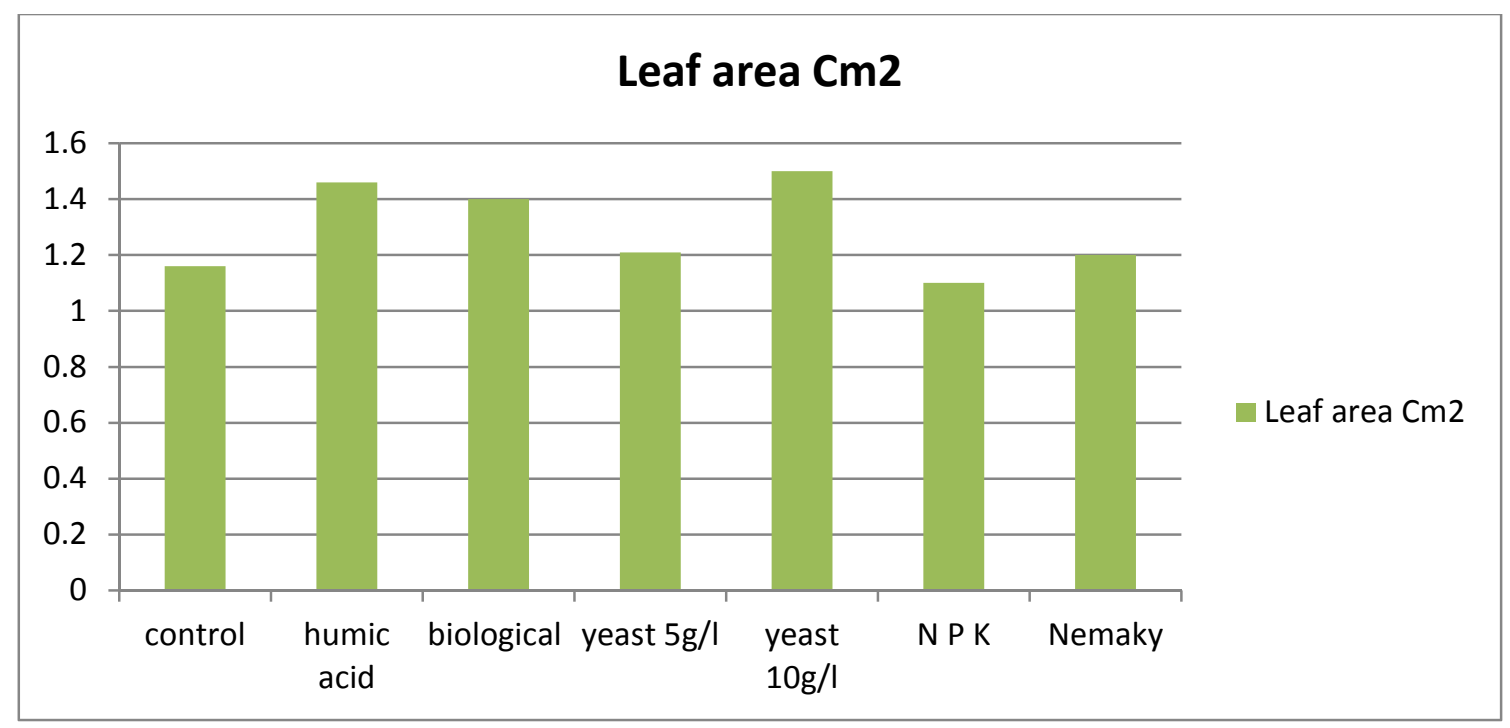

Fig. (3): Effects of treatments on cucumber yield $\left(\mathrm{kg} / \mathrm{m}^{2}\right)$ between April-August 2016.

The yeast application $\left(10 \mathrm{~g}^{-\mathrm{L}}\right)$ and humic acid $(1 \mathrm{ml}$. /plant) gave the highest significant leaf area $\left(1.5 \mathrm{~cm}^{2}\right)$ and $\left(1.4 \mathrm{~cm}^{2}\right)$ as shown in Fig. (3). Abdel-Monnem (2015) reported applying bread yeast near the plants roots with concentration of ( 4 and $8 \mathrm{~g}$ ) lead to a significant increase in the leaf area compared with the control.

The significant effect of biofertilizers (25g./1.) may be due to the fact that biofertilizers which have a positive effect on chemical composition in leaves by providing doses of nutrient to the plants and in some cases to provide plants with some promoting growth regulators (Abd El-Monem, et al., 2008). In addition, biofertilizers increase microorganisms living in the soil and these microorganisms work on the organic matter in the soil to convert organic $\mathrm{N}$ to mineral $\mathrm{N}$ (Lampkin, 1990).

Biofertilizers play a fundamental role in converting $\mathrm{P}$ and $\mathrm{K}$ fixed form to be ready soluble for plant nutrition and making the uptake of nutrients by plants easier. These results are in conformity with the findings of Supanjani, et al. (2006). Kaya et al. (2009) and Khan et al. (2012) showed that application of biofertilizers ( $\mathrm{N}$-fixing bacteria, P-dissolving microorganisms, and $\mathrm{K}$ solubilizing bacteria) increased chemical constituents of sweet pepper leaves.

\section{Conclusions}

Agroecosystem practices that increase the capacity of the ecosystem in the ways that contribute to reduce needs for surplus additions that should be emphasized in conjunction with breeding for cultivars and their associated microorganisms (Drinkwater, 2009); the role of using natural fertilizer (resources) to maintain fertility of soils and have a healthy agroecosystem throw soil fertility management can have many effects on plant quality (Wander et al., 1994).

We found evidence to suggest that natural fertilizer practices can influence the relative resistance of agricultural crops to insect pests generally. Increased $\mathrm{N}$ levels in plant tissue were found to decrease pest resistance (Phelan et al., 1995).

\section{Acknowledgements}

Special thanks to Dr. Dlshad R. A. Dim, Faculty of Agriculture. University of Kirkuk for his help in some laboratory analyses.

\section{References}

Abd El-Monem, E.A.A.; Saleh, M.M.S. \& Mostafa, E.A.M. (2008). Minimizing the quantity of mineral nitrogen fertilizers on grapevine by using humic acid, organic and biofertilizers. Res. J. Agric. Biol. Sci., 4(1): 46-50.

Abdel-Monnem, S.K. (2015). Effect of organic fertilizer and dry bread yeast on 
growth and yield of Potato (Solanum tuberosum L.). J. Agric. Food Tech., 5(1): 5-11.

Albrecht, S.L.; Baune, H.L.M.; Rasmussen, P.E. \& Douglas, C.L. (1997). Light fraction soil organic matter in long-term agroecosystems. Columbia Basin Agricul. Res. Annual Report. Spec. Report, 977: 38-42.

Barzinji, K.T. (2013). Classification of watershed in Sulaimaniyah Governorate based on database of some Morphometric characteristics, Int. Plant Anim. Environ. Sci., 3(2): 203-221.

Bauer, A. \& Black, A. (1994). Quantification of the effect of soil organic matter content on soil productivity. Soil Sci. Soc. Am. J., 58: 185-193.

Bonanomi, G.; D'Ascoli, R.; Scotti, R.; Gaglione, S.A.; Caceres, M.G.; Sultana, S.; Scelza, R.; Rao, M.A. \& Zoina, A. (2014). Soil quality recovery and crop yield enhancement by combined application of compost and wood to vegetables grown under plastic tunnels. Agr. Ecosyst. Environ., 192: 1-7.

Bouyoucos, G.J. (1936). Directions for making mechanical analysis of Soils by the hydrometer method. Soil Sci., 4: 225-228.

Bown, G.D. \& Rovira, A.D. (1991). The rhizosphere, the hidden half of the hidden half. Pp. 641-669. In: Waisel, Y.; Eshel, A. \& Kalkaf, V. (Eds.). Plant Roots, the Hidden Half Marcel Dekker. New York. Camb. 104: 224pp.

Bulluck, L.R.; Brosius, M.; Evanylo, G.K. \& Ristaino, J.B. (2002). Organic and synthetic fertility amendments influence soil microbial, physical and chemical properties on organic and conventional farms. Appl. Soil Ecol., 19: 147-160.

Drinkwater, L.E. (2009). Ecological knowledge: foundation for sustainable organic agriculture. In: Francis, C. (Ed.). Organic Farming: The Ecological System. Agronomy monograph 54. Soil Sci. Soc. Am., Madison, W.I.: 47pp.
FAO (1976). A framework for land evaluation, FAO, Rome, Soil Bulletin: 32pp.

Joshi, V.K.; Sharma, S. \& Devi, M.P. (2009). Influence of different yeast strains on fermentation behavior, physico-chemical and sensory qualities of plum wine. Natural Product Radiance, 8(4): 445-451.

Kaya, C.M.; Sonmez, O.; Tuna, A. \& Culla, M.A. (2009) the influence of arbuscular mycorrhizal colonization on key growth parameters and fruit yield of pepper plants grown at high salinity. Scienta Horticulturae, 1(21): 1-6.

Khan, Z.S.A.; Tiyagi, S.A.; Mohmood, I. \& Rizvi, R. (2012). Effect of $N$ fertilization, organic matter and biofertilizers on growth and yield of chilli in relation to management of plant-parasitic nematodes. Turk. J. Bot., 3(6): 73-81.

Lampkin, N. (1990). Organic Farming. Farming Press. Books and VideoWharfedule Road, Ipswich (P) 4 LG. U.K.: $701 \mathrm{pp}$.

Larkin, R.P. (2008). Relative effects of biological amendments and crop rotations on soil microbial communities and soil borne diseases of potato. Soil Biol. Biochem. 40,: 1341-1351.

Maurya, G.P.; Pal, V.; Singh, G.P. \& Meena, L.K. (2015). An economic analysis of cucumber cultivation in Sultanpur District of Uttar Pradesh (India). Intern. J. Agric. Sci. Res., 5: 23-28.

Mclean, E.O. (1982). Soil $\mathrm{pH}$ and lime requirement. Pp: 199-224. In: Page, A.L., (Ed.). Methods of Soil Analysis. Part 2. Chemical and Microbiological Properties, American Society of Agronomy, Soil Science Society of America, Madison: $1173 p p$.

Olsen, S. R.; Cole, C. V.; Watanabe, F. S. \& Dean. L. A. (1954). Estimation of available phosphorus in soils by extraction with $\mathrm{NaHCO}_{3}$, USDA Cir.939. U. S. Washington.: 19pp. 


\section{Abdul Rahman \& Yüksal / Basrah J. Agric. Sci., 31 (2): 68-75, 2018}

Palm C.A., Myers R.J.K. and Nandwa S.M. (1997). Combined use of organic and inorganic nutrient sources for soil fertility maintenance and replenishment. Pp: 193217. In: Buresh R.J., Sanchez P.A. and Calhoun F. (Eds.). Replenishing soil fertility in Africa, SSSA, American Society of Agronomy, Madison, Wisconsin: 264pp.

Patil, P.L.; Pulakeshi, H.B.P. \& Dasog, G.S. (2012). Identification of soil fertility constraints by Geographic Information System (GIS) technique and response of crops to identified nutrient constraints in northern transitional zone of karnataka. The Third National Conference on AgroInformatics and Precision Agriculture 2012 (AIPA 2012), At: Hyderabad, India,: 232236.

Phelan, P.L.; Mason, J.F. \& Stinner, B.R. (1995). Soil fertility management and host preference by European corn borer Ostrinia nubilalis, on Zea mays a comparison of organic and conventional chemical farming. Agric. Ecosyst. Environ., 5(14): 23-34.

Richards, L.A. (1954). Diagnosis and Improvement of Saline and Alkali Soils. USDA Agriculture Handbook 60, Washington, D. C.: 160pp.

Sarhan, T.Z. (2008). Effect of biological fertilizers, Animed residues, and Urea on Growth and yield of potato plant C.V. Desiree Solanum tuberosum L. Ph. D. Thesis.. Coll. Agric. For. Univ. Mosul: $121 \mathrm{pp}$.
Siful, M.S. (2008). An economic analysis of Cucumber cultivation in selected area of Mymensingh District. M.S. Thesis. Mymensingh, Bangladesh Agricultural University: 126pp.

Supanjani, H.S.; Jung, S.J. \& Lee, K.D. (2006). Rock phosphate potassium and rock solubilizing bacteria as alternative sustainable fertilizers. Agro. Sustain. Develop., 26: 233-240.

Vollrath, D. (2011). The agricultural basis of comparative development. J. Econ. Growth, 16: 343-370.

Walkley, A. \& Black, I. A. (1934). An examination of Degtjareff method for determining soil organic matter and a proposed modification of the chromic acid titration method. Soil Sci., 37(1): 29-37.

Wander, M.M.; Traina, S.J.; Stinner, B.R. \& Peters, S.E. (1994). Organic and conventional management effects on biologically active soil organic matter pools. ACSESS, 58(4): 1130-1139.

Wang, K.H. \& McSorley, R. (2005). Effects of soil ecosystem management on ematode pests, nutrient cycling, and plant health, APSnet Features: doi: 10.1094 /APSnetFeatures/2005-0105.

Wilde, J. (2013). How substitutable are fixed factors in production? Evidence from preindustrial England. Working paper 0113, Univ. South Florida, Dep. Economics. 514pp. 